\title{
II がん登録制度
}

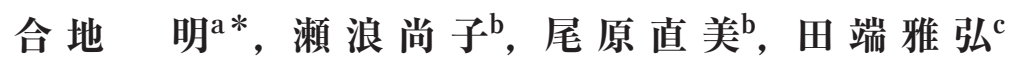

岡山大学医学部・歯学部病院 a医療情報部, b病歴管理室, c腫瘍センター

キーワード : 院内がん登録, 地域がん登録, case finding

\section{はじめに}

平成18年10月から岡山大学病院もがん診療連携拠点 病院の認可を受け，本格的に活動を始めています。そ の中の 1 つの業務として院内がん登録が含まれていま す. 岡山県では岡山県保健福祉部の指導のもと県医師 会を中心とした地域がん登録がすでにおこなわれてい ますが当院の登録状況は極めて限られており, 現状の ままでは，院内がん登録についても正しい報告がおこ なえない可能性があります。

今回この場を借りましてがん登録の意義, 院内がん 登録と地域がん登録の関連ならびに岡山大学病院にお ける現状につき言及させていただき，ご理解いただけ ればと存じます。

\section{がん登録の概要と必要性}

がんの罹患率と死亡率の激減を目標にした第 3 次対 がん10力年総合戦力はがん研究の推進, がん予防の推 進，がん医療の向上とそれを支える社会環境整備の 3 本柱の上に成り立っている. がん研究の推進の 1 項目 にがんの実態把握とがん情報・診療技術の発信・普及 があげられている。つまり，まず，がん診療の実態を 正しく把握した上で治療成績の向上を含めた均てん化 の促進を進めようという方針である. 各種がんの生存 解析に扔いて地域間格差ならびに施設間格差が見られ たという報道に接したことは記憶に新しいところであ る，具体的にがん登録を㧍こなうことにより，各種が んの罹患数の把握によりリスク要因の同定ならびに予

平成19年 3 月受理

*テ700-8558 岡山市鹿田町 2-5-1

電話：086-235-7976 FAX：086-235-7976

E-mail : agouchi@hp.okayama-u.ac.jp
防対策の実行が可能となり，また，進行度解析により 検診プログラムの普及と品質管理システムの確立が可 能となる。治療成績の解析からは治療法に対する対策 が見えてくる．このように現時点のがん診療の実態を 把握することが必要不可欠である.

がん登録の大きな流れは図 1 に示すとおりである.

\section{地域がん登録と院内がん登録（表 1)}

がん登録についてはすでに学会が主導しておこなわ れている各種臟器別がん登録, 健康増進法に基づいて おこなわれている地域がん登録および今回のがん対策 基本法に基づくがん診療連携拠点病院に課せられた院 内がん登録の 3 種類がある。

これら 3 種類のがん登録は目的が異なるため扔のお のの悉皆性，粒度が異なっている．たとえば，学会主 導の臟器別がん登録においては手術症例に重点が扔か れるため, 術後の化学療法での再入院状況などがもれ やすく，また，複数科にまたがる症例に打いては複数 登録される可能性も生じる。

地域がん登録に扔いても全国で34の道府県市の自治 体で㧍こなわれているがその精度に関しては不十分で ある.地域がん登録制度による罹患数把握に打いても DCN (Death Certificate Notifications : 死亡診断書に よりはじめてがんを把握）あるいはDCO（Death Certificate Only : 死亡診断書以外の情報がない）など 正確な情報把握ができていないのが現状である。この ため祖父江班に损いては登録項目の整備による地域が ん登録の標準化の推進とともに国際比較に対応できる 精度向上のための研究が進められている.

ところで個人情報保護法の絡みで地域がん登録事業 を廃止した自治体も出たがこれに関しては2004年 1 月 健康局長通知で『利用目的の制限』、『第三者提供の制 限』,『利用抢よび提供の制限』の適用除外として扱わ 
れることとなっている.

\section{がん診療連携拠点病院の院内がん登録}

2007年 1 月31日現在全国で284の施設ががん診療連 携病院の指定を受け，院内がん登録の整備，稼動がお こなわれている。

院内がん登録の標準的な手順は図 2 に示すとおりで ある。基本的には病院情報システムから対象患者の抽
出を行い，可能な限りの情報を病院情報システムから 取得，診療情報管理士（将来的には腫瘍登録士?）が 監査を行い，不備な点を主治医に問い合わせを行い， 正確な情報を入力し，確定登録することとなる，がん 登録の実施主体は主治医となるが，加重業務を軽減さ せるためにできる限り病院情報システムに入力された デー夕を有効活用する方策が検討されている.

がん登録の趣旨特に悉皆性の点から登録対象の洗い

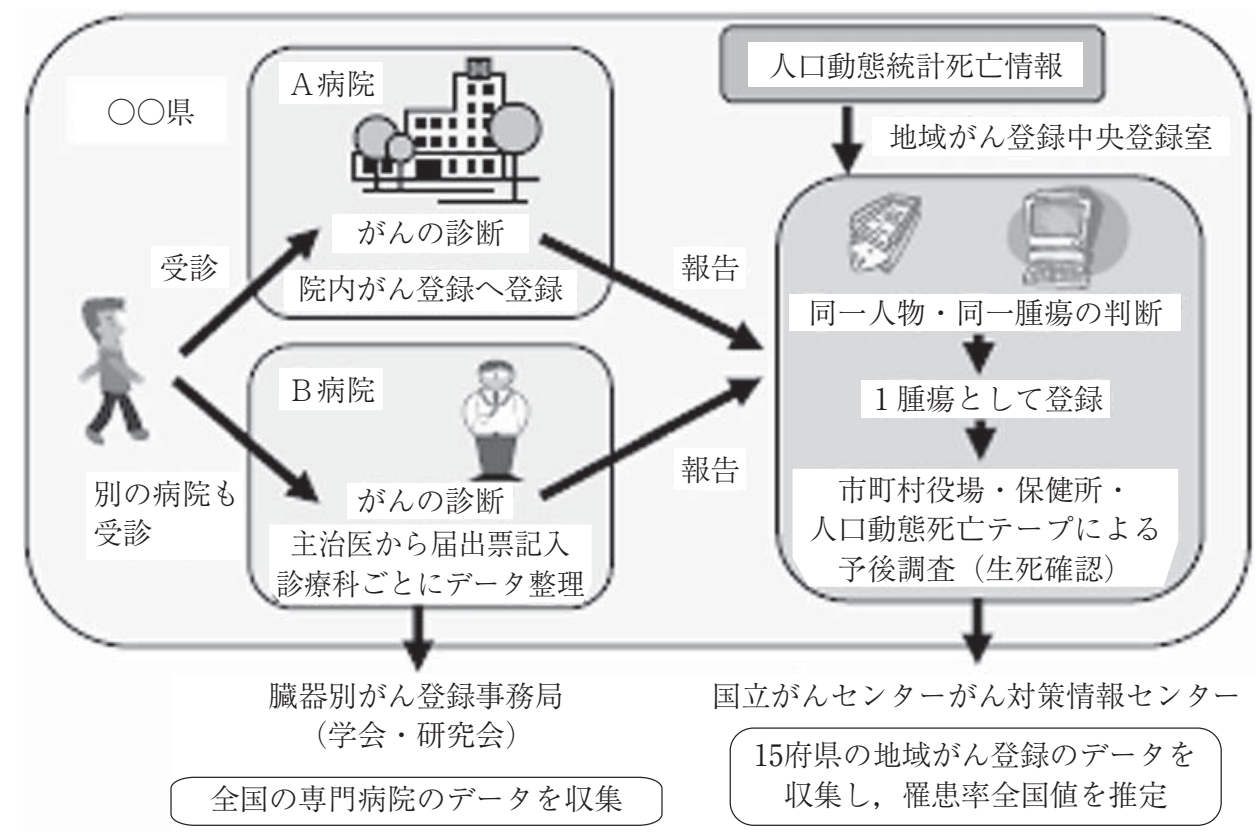

図 1 がん診療拠点病院からのがん登録の流れ（がん登録実務者研修会資料より）

表 1 各種がん登録の実態（がん登録実務者研修会資料より）

\begin{tabular}{|c|c|c|c|}
\hline & 地域がん登録（県単位） & 院内がん登録（施設単位） & 臓器別がん登録(臓器単位) \\
\hline 的 & 地域のがん実態把握 & 施設のがん診療評価 & $\begin{array}{l}\text { 全国のがんの詳細情報の収 } \\
\text { 集 }\end{array}$ \\
\hline 実施主体 & 都道府県（市） & 医療機関 & 学会·研究会 \\
\hline 登録対象 & 対象地域の全がん罹患例 & 当該施設の全がん患者 & 専門病院のがん患者 \\
\hline 収集 項目 & $\begin{array}{l}\text { 診断, 初回治療, } \\
\text { 予後：標準25項目 (2004年) }\end{array}$ & $\begin{array}{l}\text { 診断, 初回治療, } \\
\text { 予後：必須・標準 } 60 \text { 項 目 } \\
\text { (2006年修正版) }\end{array}$ & $\begin{array}{l}\text { 臓器により異なるが, 項目 } \\
\text { 数は多い（200～300項目） }\end{array}$ \\
\hline 状 & 34 道府県 1 市にて実施 & 全がん協加盟30施設 & $\begin{array}{l}\text { 10〜20臓器が助成金研究班 } \\
\text { に参加 }\end{array}$ \\
\hline 問 題 点 & $\begin{array}{l}\text { - 罹患の把握漏れが多い } \\
\text { ・標準化の遅れ } \\
\text { ・予後調査未実施・負担大 }\end{array}$ & $\begin{array}{l}\text { - 診療科単位の登録 } \\
\text { - 医師による入力 } \\
\text { - 腫瘍登録士の不足 } \\
\text { - 標準化の遅れ } \\
\text { - 不完全な予後調査 }\end{array}$ & $\begin{array}{l}\text { ・個人情報の扱い } \\
\text { ・不完全な予後調査 }\end{array}$ \\
\hline
\end{tabular}


出し作業 (case finding) が非常に重要な作業となる. この case findingのための情報ソースとしては病名, 病理組織診断, 手術術式, 抗がん剂処方歴, 放射線治 療歴, 内視鏡検査やレントゲン検査報告書などさまざ まな診療情報があげられる。これらのうちで比較的有 用と考えられるものは病名拉よび抗がん剂の処方など である.しかし，早期の大腸癌や胃癌などでは必ずし も抗がん剂使用の対象とはならない。疾患の特性から 考え, やはり, 病名を重視するのがもっとも迅速な方 法と考えられる.

また, 外来, 入院での 1 患者 1 腫瘍デー夕を管理す る点からは患者ごとの入院毎あるいは外来における動 態を厳重に登録管理していくことも重要である。この ようなシステムの整備が今後必要となってくる.

登録必須項目の多くは病院情報システムからの抽出 が可能であるが進行度，入院期間中の治療内容等に関 しては直接, 主治医からの情報入力してもらうのが迅 速かつ正確である。 また, 今回の収集デー夕の中で最 も入手困難とされる ICD-O3M に関する情報は病理 医との連携が必要不可欠である。

このように院内がん登録は病院上げての協力体制に おいて, 初めて可能となることを十分認識する必要が ある。

\section{がん診療連携拠点病院とがん登録}

がん診療連携拠点病院設立の経緯に関しては別項で 述べられていると㧍りであり，ここではがん診療連携

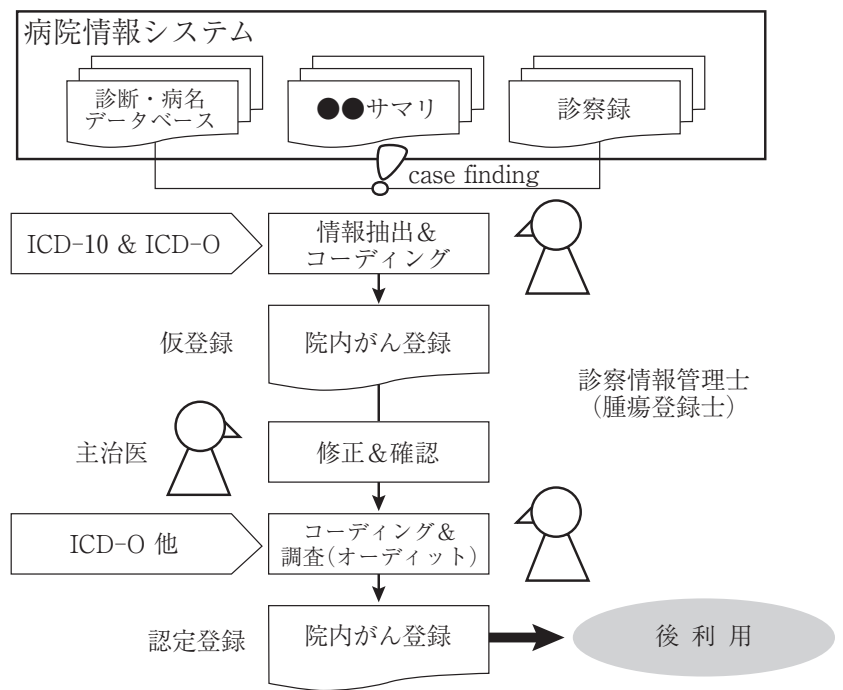

図 2 がん登録の標準的手順 （がん登録実務者研修会資料より）
拠点病院としてのがん登録への取り組みに関する責務 について触れることとする．先述のように第 3 次対が ん10力年総合戦略の目標達成のひとつの手段であるが んの実態把握のためには必要不可欠な業務である。し たがって，指定要件にも標準様式に基づく院内がん登 録の実施と地域がん登録への積極的協力がうたわれて います。また, 都道府県がん診療連携拠点病院の機能 として協議会を設置し, 都道府県に扮ける院内がん登 録データの分析・評価が義務付けられている.

\section{岡山大学病院における院内がん登録手順}

現在，岡山大学病院においても2006年10月以降暫定 システムに拈いて入院患者を対象とする院内がん登録 を開始している．がん登録の本来の意義から考えれば 将来的には外来患者の把握も必要となってくる. 現段 階の流れにつき，解説しておきたい。

\section{Case finding (表 2)}

入院患者を対象としては現行では包括医療制度下に おいて入院時の DPC コードの取得作業が必須となっ てくる．幸いにして岡山大学病院では入院申し込みを 利用した診療計画書の作成情報をもとに入院時の DPC コード付けを診療情報管理士が扔こなっており， この時点でがん患者か否かの判定が可能である.

がん患者であることが明らかな症例に関して院内が ん登録の書き込みを促すメッセージを電子カルテの掲 示板を通じておこなっている.

これ以外に中間サマリ情報からの最新 DPC コード 付けもおこなっているので新たにがん患者であること が明らかになった場合も主治医に登録の催促が可能で ある。

\section{2. 院内がん登録の標準登録様式}

先述のごとく，院内がん登録，地域がん登録，学会 の藏器別がん登録の粒度はそれぞれの目的により異な っている.ただし，前 2 者についてはかなりの項目で 共通する部分が見られるため当局との間で整理作業を おこなっている。ところが臓器別がん登録とは接点が 少ないことからは当面両者を切り離し，登録作業をお こなっていただく必要がある。将来的には病院情報シ ステムに取り込まれた情報のひとつとして連携してい くことを考えたい。

また，ICD-O3M の情報収集体制については病理部 のご協力をいただくことになっており，当院において は比較的スムーズに対応可能と考えている. 
表 2 ケースファインディングのための材料（がん登録実務者研修会資料より）

\begin{tabular}{|c|c|c|c|}
\hline 情 報 源 & 情報源の含まれる資料 & 入手 先 & 利用法, 具体例等 \\
\hline 退院時病名 & $\begin{array}{l}\text { 医療情報関連データベース, 退院 } \\
\text { 時サマリー }\end{array}$ & 医療情報関連部門 & $\begin{array}{l}\text { 毎月悪性病名を持っている患者を } \\
\text { 抽出 }\end{array}$ \\
\hline 外来病名 & $\begin{array}{l}\text { 医療情報関連データベース, 外来 } \\
\text { 診療録 }\end{array}$ & 医療情報関連部門 & $\begin{array}{l}\text { 毎月悪性病名を持っている患者を } \\
\text { 抽出 }\end{array}$ \\
\hline 病理診断病名 & $\begin{array}{l}\text { 病理診断データベース, 病理報告 } \\
\text { 書 }\end{array}$ & 病理・細胞診断部門 & $\begin{array}{l}\text { 定期的に悪性診断名（コード）を } \\
\text { 持っている患者を抽出 }\end{array}$ \\
\hline 細胞診病名 & $\begin{array}{l}\text { 病理診断データベース, 病理報告 } \\
\text { 書 }\end{array}$ & 病理・細胞診断部門 & $\begin{array}{l}\text { 定期的に悪性診断名（コード）を } \\
\text { 持っている患者を抽出 }\end{array}$ \\
\hline 手術台帳の病名記録 & 手術台帳 & 手術部門，医療情報関連部門 & 悪性病名を持っている患者を抽出 \\
\hline 放射線診断病名 & $\begin{array}{l}\text { 放射線診断部門データベース，報 } \\
\text { 告書 }\end{array}$ & $\begin{array}{l}\text { 医療情報関連部門，放射線診断部 } \\
\text { 門 }\end{array}$ & 悪性病名を持っている患者を抽出 \\
\hline 放射線治療病名 & $\begin{array}{l}\text { 放射線治療部門データベース，照 } \\
\text { 射記録，報告書 }\end{array}$ & $\begin{array}{l}\text { 医療情報関連部門，放射線診断部 } \\
\text { 門 }\end{array}$ & 悪性病名を持っている患者を抽出 \\
\hline 死因 & 死亡診断書 & 医事課 & $\begin{array}{l}\text { がん・腫瘍の記載のある死亡診断 } \\
\text { 書を抽出 }\end{array}$ \\
\hline 診療部門ごとの情報 & $\begin{array}{l}\text { 各診療部門データベース, 臓器が } \\
\text { ん登録 }\end{array}$ & 各診療部門 & 登録患者のもれチェックも可能 \\
\hline 入院がん登録情報 & 入院ごとのがん患者に関する情報 & 医療情報関連部門 & 毎月の登録患者を抽出 \\
\hline
\end{tabular}

\section{3．登録情報の抽出，集計}

1 患者 1 腫瘍 1 登録の原則に従っており, 現行では 入院毎の情報を入力していく方針のため短期化学療法 による再入院時などにおいては主治医に多大な付加に なっているががん登録の理念からはやむを得ないこと を十分ご理解いただきたい。基本情報等重複入力は避 けるようにシステムの改善をおこなっている.

\section{4. 予後調查}

予後調査の方法としては戸籍照会，住民票照会，患 者・家族への直接照会, 紹介医療機関間の情報連携お よび地域がん登録からの情報還元などがある.

現状では各診療科でおこなっている方法により調査 していただき報告していただきたい。岡山県では県医 師会を中心とした地域がん登録システムにおける追跡 調査もきわめて精度の高い情報として利用できるので 活用していくことも考えています.

\section{5.がん治療の現状統計デー夕の作成と開示}

現在集積しているデータが整備されれば将来的には 当院における治療成績をはじめとする各種統計の作 成，開示が容易におこなえることとなります。
以上のように院内がん登録システム稼働後 6 ケ月の 現状システム自体も暫定版ということで皆様方に多大 なご迷惑をおかけいたしておりますがよりスムーズな 連携のためにご意見をいただき一つ一つ改善していく ことが重要と考えます。

\section{文献}

・国立がんセンターがん対策情報センター がん情報サービ 又 院内がん登録支援情報

http : //ganjoho.go.jp/base/cancer registration/index.html

・厚生労働省第 3 次対がん総合戦略事業「がん予防対策のため のがん罹患・死亡動向の実態把握の研究」班：第 3 次対がん 総合戦略研究事業開始時点における地域がん登録実施状況調 査（事前調査）結果報告書 (2005).

・祖父江友孝：がん対策・1がん登録の意義と課題（1)がん登 録の意義とその有効活用例．公衆衛生（2007）71(1)，27-30.

・山崎 晋：がん登録はがん治療の「精度管理システム」であ る. 日本癌治療学会誌 (2006) 41(2), 219.

・祖父江友孝：わが国のがん登録の体制整備について．呼吸 (2007) 26(1), 31-35.

・がん診療連携拠点病院 院内がん登録 標準登録様式 登録項 目とその定義 2006年度版修正版 解釈本

- 厚生労働省大臣官房統計情報部編：国際疾病分類一腫瘍学 (第 3 版） ICD-O. 